Article

\title{
Socio-Economic Benefits Stemming from Bush Clearing and Restoration Projects Conducted in the D'Nyala Nature Reserve and Shongoane Village, Lephalale, South Africa
}

\author{
Tshepiso Mangani ${ }^{1,2, *}$, Hendri Coetzee ${ }^{3,4}$, Klaus Kellner ${ }^{1}$ and George Chirima ${ }^{2,5}$ \\ 1 School of Biological Sciences and Unit for Environmental Sciences \& Management, North-West University, \\ Private Bag X6001, Potchefstroom 2520, South Africa; Klaus.Kellner@nwu.ac.za \\ 2 Institute for Soil, Climate and Water, Agricultural Research Council, Pretoria 0083, South Africa; \\ chirimaj@arc.agric.za \\ 3 Office for Sustainability and Community Impact, North-West University, Private Bag X6001, \\ Potchefstroom 2520, South Africa; Hendri.Coetzee@nwu.ac.za \\ 4 Community Psychosocial Research [COMPRES], North-West University, Private Bag X6001, \\ Potchefstroom 2520, South Africa \\ 5 Department of Geography, Geoinformatics and Meteorology, University of Pretoria, Pretoria 0083, \\ South Africa \\ * Correspondence: ModungwaR@arc.agric.za
}

Received: 9 May 2020; Accepted: 16 June 2020; Published: 24 June 2020

\begin{abstract}
This study aimed to investigate the socio-economic benefits stemming from bush clearing and restoration projects conducted in the Lephalale municipality, within the Limpopo Province of South Africa. The study was conducted at two sites: the D'Nyala Nature Reserve and a nearby local village, Shongoane. A qualitative thematic content analysis approach and semi-structured interviews were used to gather data from 14 purposively selected participants between the ages of 22 and 55 ( male $=9$ and female $=5$ ). The results indicated that the nature reserve benefited from the project via the improved visibility of the landscape features and game viewing, which made the reserve more attractive for tourists and resulted in increased revenue. The costs of buying feed for game could also be curbed since the grazing capacity increased. Since the nature reserve sourced temporary labour from the local village to execute the project, the community benefited in terms of members being able to earn a wage, which led to an improvement in their livelihoods. Another indirect benefit was the morale and behavioural changes observed amongst community members. It was obvious that the socio-economic benefits derived from projects such as these far outweigh the negatives and that there is every reason to institute projects of a similar nature elsewhere.
\end{abstract}

Keywords: bush clearing; local community; nature reserve; restoration project; socio-economic benefit

\section{Introduction}

The complex link between biodiversity and ecosystem services (social benefits) is yet to be understood. Previously, scientists took into account the conservation of biodiversity from a biophysical perspective [1-3]. In some cases, researchers found that although feasible, these conservation activities were not always sustainable $[4,5]$. This is mainly because local communities where conservation activities are practised [6,7] were not often involved and did not directly benefit from these activities [3,5].

Recently, there has been more of a focus on how local communities can become involved in and simultaneously benefit from conservation attempts, such as the restoration of degraded lands [7-9]. Some of the proposed strategies include short-term economic interventions aimed at 
improving the livelihoods of local communities by, for example, creating temporary job opportunities, skills development, and training [10]. As is evident from the literature, though, the results of some of these efforts are rather contradictory.

For example, Arnold et al. [11] and DeCaro and Stokes [12] found that community and stakeholder involvement in the decision-making process does not always guarantee positive outcomes, while other studies such as Bernhardt et al. [13] found a positive correlation between direct community involvement and ecological restoration success. A report by Dorondel et al. [3] emphasised that in a great deal of projects that were done in the Danube floodplain, ecological restoration could not be implemented without the approval and participation of the local community.

This combination of uncertainty about a conservation project's outcomes and the pressure to succeed can result in uneasiness playing a significant role in local community behaviour [5]. Usually, this can be ascribed to the community's inability to envisage the long-term benefits they could derive from projects. Although communities expect to derive some form of benefit from conservation activities that will enrich their livelihoods, they tend to see projects as only benefiting project owners. For this reason, as far as the actual process of restoration implementation is concerned, Druschke and Hychka [14] argued that communication and mutual cooperation are key, because they shape the quality of community engagement, which in turn, can translate to all parties benefiting (or at the very least ensure buy-in and support from the local community).

Despite the mixed results obtained regionally and globally, Reid [15] concluded that, in essence, community-based restoration projects offer not only economic benefits but also knowledge and experience that communities can use to empower themselves, which will lead to the improvement of their livelihoods.

For example, a study conducted by Fox et al. [16] found that river restoration projects in the United States, Canada and New Zealand have the potential to not only restore ecosystem processes and services but to benefit the community by repairing and transforming human relationships. Even though the latter may not have a direct economic benefit, restored and transformed human relationships serve to create a cooperative space for dialogue and hold the promise of future cultural and educational benefits for the community. Similarly, Browder [17] found that even though economic development impacts were mixed in the Brazilian Amazon conservation and development project, approximately $50 \%$ of the projects delivered tangible benefits to local communities.

In their study of eight of the river restoration projects being conducted across Europe, Muhar et al. [18] also quantified the effect of restoration on ecosystem services. Included as benefits were the provisioning of agricultural products, wood and infiltrated potable water, as well as regulation and cultural services such as recreation and biodiversity conservation. The latter study's findings are supported by Vermaat et al. [19] who reported that river restoration projects showed a marked increase in ecosystem services over and above other benefits such as the economic upliftment of the community. The economic evaluation of wetland-based community participation was studied by Roy et al. [20]. In that study, it was highlighted that the stakeholders' livelihoods were uplifted through wetland conservation.

In another study involving the use of bush-encroached and gullied areas in India to produce biofuel by planting Jatropha, Francis et al. [10] found that the restoration activities helped to generate rural employment and increased environmental quality. In this instance, community members were involved in labour-intensive activities of clearing and replanting. The long-term effect of this restoration project was the improvement of degraded lands which could not be used for food production but were subsequently put to use to improve the livelihoods of local communities. In principle, land degradation can be effectively managed if the principal ecological, socio-cultural, and economic driving forces are properly understood [21]. With that said, the active involvement of local communities not only benefits them but also plays a crucial role in identifying and solving problems at the project site [21].

Given that economic and social conditions and resource availability in poor and developing countries differ considerably from those in developed countries [10], it is imperative to keep in mind 
that these communities are largely dependent on land for agriculture, fuel and water to sustain the livelihoods of the rural poor [22,23]. Furthermore, communities in these countries often fall prey to prevailing climatic variations [15] and are characterised by high population densities and low skill levels [24].

Nevertheless, in his study of soil organic carbon pools in developing countries, Lal [25] demonstrated how acquiring new knowledge and skills (education) with regard to soil conservation that will eventually lead to higher productivity of land resources can benefit communities directly and indirectly. Note, though, that success in this instance was ascribed to first understanding the needs of the local farmers and then learning how to manage the state of the land.

Another case in point would be that of Namibia where land degradation, involving both bush encroachment and the spread of invasive alien plant species, was found to be an important driver of ecosystem decline [26,27]. This realisation led to restoration projects to clear bush-encroached and invaded areas by involving community members. In this instance, Stafford [27] found that the resultant benefits for the socio-economy and social development far outweighed the restoration of the land itself.

In sum, as Adams and Hutton [28] pointed out, "the compatibility of conservation and poverty alleviation" is bound to have social and economic impacts. Moreover, in terms of local community development, restoration activities should be sustainable over the long term rather than only impacting livelihoods during the course of the activities.

\section{Socio-Economic Benefits of Restoration Projects in South Africa}

South Africa is a water-scarce country with rangelands covering almost $60 \%$ of the country $[29,30]$. Some of the worst degradation of these rangelands can be observed in communal areas and can be ascribed not only to poor land management but also to the high density of the population in these areas [22]. The Limpopo province, the study area, with a population density of more than 46 people per $\mathrm{km}^{2}$, is thought to be one of the most degraded in South Africa, particularly in the communal areas [31,32]. Much of the degraded area $(56 \%)$ was land primarily used for the grazing of domestic animals [33]. It is further estimated that $16 \%$ of the province is infested with alien invasive plants [33], which have necessitated restoration projects. Poor land management combined with drought conditions, especially in arid- and semi-arid ecosystems, poses a threat to the long-term productivity of the land, especially where communally managed lands are further degraded as a result of bush encroachment and the invasion of alien species [23,34]. Recognising this, and that a large proportion of the population is dependent for their livelihoods on services derived from dryland ecosystems, South Africa ratified the United Nations Convention to Combat Desertification (UNCCD) in countries experiencing serious drought and/or desertification in 1997. The country prepared a National Action Programme (NAP) combating land degradation to alleviate rural poverty [35]. Furthermore, a national programme called Working for Water (WfW), launched in 1995, is aimed at removing invasive alien plants to reduce competition from unwanted plants and to increase land productivity potential [36].

Given that Lukomska et al. [34] found that de-bushing restoration techniques proved to conserve and increase grazing capacity resulting in generating a higher and sustainable income for local farmers, a detailed study of such projects in semi-arid areas that can be linked directly or indirectly to socio-economic benefits for local communities is warranted.

Relatively few data exist regarding restoration programmes across South Africa, particularly regarding the reconciliation thereof with social goals. By way of background, South Africa's Department of Environment, Forestry and Fisheries (DEFF) has been tasked with the restoration of degraded lands on a national scale, a responsibility which by inference encompasses research and social development projects. In response, the department implemented the Natural Recourse Management (NRM) and Expanded Public Works (EPWP) programmes. Given that this study set out to investigate the benefits of bush clearing and restoration projects from a socio-economic rather than a biophysical perspective, only those projects under the NRM are relevant here. 
Overall, the objective of the DEFF-NRM programme is to ensure the sustainable land management of rangelands and to improve the socio-economic livelihoods and promote the well-being of people in rural areas. It encompasses a number of "working for" projects, all of which are labour-intensive. Included here is Working for Water (WfW), which involves projects to control invasive species (alien and indigenous), as well as Working for Ecosystems (WfEco) and Working for Land (WfL), both of which aim to address degraded ecosystems and to provide sustainable ecosystem services for rural communities in the long term (www.environment.gov.za). This study reports on the WfW, WfEco and WfL programmes specifically in as far as controlling bush-encroached rangelands is concerned.

Promoting an understanding of how nature works and how it can provide for everyday needs if protected is the obvious point of departure. However, it is imperative that those responsible for implementing bush clearing and restoration projects should also make it their business to gain an understanding of the value local communities attach to the ecosystem services they derive from natural resources if their projects are to succeed [13]. In short, the restoration of degraded rangelands should not be restricted to environmental conditions only, but should also encompass active intervention in as far as social and economic conditions are concerned [37].

Given South Africa's extremes of unemployment and poverty, many families regularly experience hunger and find it difficult to meet their basic needs [38]. In the Lephalale municipality, the unemployment rate sits at $22.2 \%$ with a dependency ratio of $33.2 \%$ and $39.1 \%$ female-headed households, mostly in rural communities [38]. One of the short-term goals in the municipality was to generate employment, especially in projects involving the improvement of the environment. Considering the lack of research on how to involve local communities in restoration activities and how to optimise the socio-economic benefits they derive from being involved in such activities, this study set out to develop a decision support system (DSS) for all stakeholders, especially land users and policy makers. This was so that informed decisions could be made about the benefits derived from the restoration of degraded lands. To this end, two sites in the Lephalale municipality in the Limpopo Province where members from the community partook in bush clearing and restoration activities were investigated in an attempt to quantify the socio-economic benefits addressed in the process.

\section{Methods}

\subsection{Study Area}

This study was carried out at Lephalale, a municipality in the Limpopo Province, South Africa $\left(23^{\circ} 40^{\prime} \mathrm{S} 27^{\circ} 45^{\prime} \mathrm{E}\right)$ (Figure 1). Lephalale is a coal-mining town and has a semi-arid climate, with a rainfall of $350-500 \mathrm{~mm} / \mathrm{y}$ and maximum temperatures rising to $38.2^{\circ} \mathrm{C}$. The municipality has a population of 140,240 with 43,002 households in total and a dependency ratio of $33.2 \%$ [38]. Two sites where bush clearing and restoration projects have been implemented were visited to conduct interviews, namely: (1) D'Nyala Nature Reserve, which lies $15 \mathrm{~km}$ south-east of Lephalale, and (2) Shongoane, a village in the north-eastern rural part of Lephalale. 


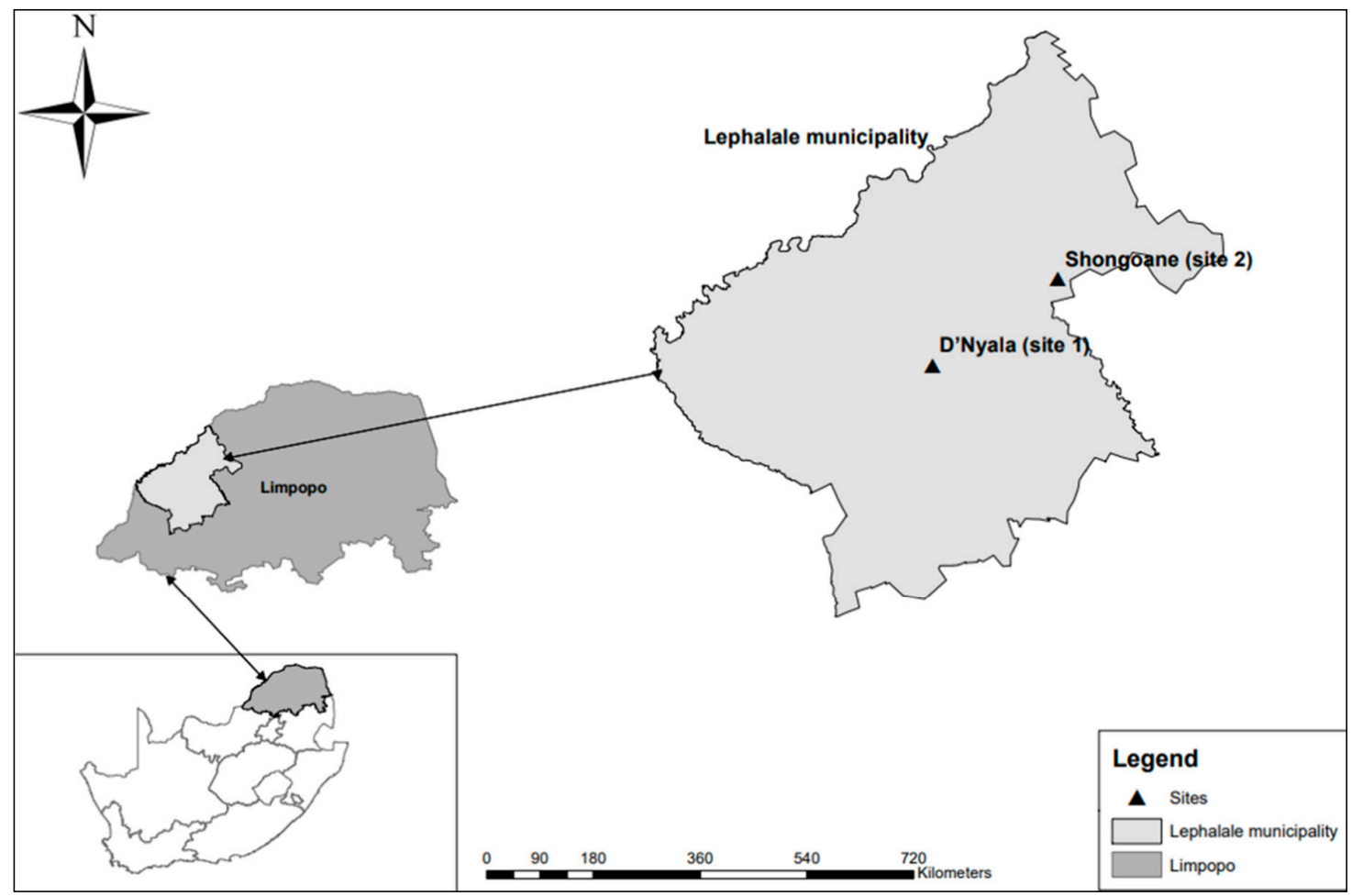

Figure 1. Study area.

Here, it ought to be noted that D'Nyala is considered a protected area in South Africa and is earmarked by the Department of Environmental Affairs as an area where projects to curb bush encroachment should be prioritised in order to protect biodiversity and to ensure the long-term sustainability of the reserve.

The D'Nyala Nature Reserve is approximately 8000 ha in size [38]. Socio-economically, the reserve plays an important role since it employs many people from surrounding villages, but mostly Shongoane, to take care of bush clearing and restoration work within its boundaries. Shongoane, one of many villages dotted around Lephalale, is managed communally. Here, livestock is allowed to graze freely and, unlike in the nature reserve, the number of animals accommodated within the area is not kept in check. In the case of Shongoane, most of those employed to handle bush clearing and restoration reside in the village.

\subsection{Approach and Strategy}

The purpose of the study was to investigate what socio-economic benefits were received by the community members that partook in bush clearing and restoration activities. The objective was therefore to evaluate and quantify the socio-economic benefits addressed in the process on a small scale. A qualitative, thematic content analysis approach was used.

Given that qualitative research is defined by the nature of the questions asked [39,40], the concept and methodologies were adapted during the design of this study, and the analysis and interpretation were associated with assumptions made when collecting the data [41]. This approach was followed because the study sought to arrive at an understanding of the benefits derived from bush clearing and restoration projects from the perspective of those who actually benefited and, as pointed out by Hammersley [42], because qualitative research provides a more comprehensive and better understanding of the relationships between people and the environment. 


\subsection{Participants}

Although around 400 people from villages in Lephalale partook in the bush clearing and restoration activities, only 25 of those were directly involved at both the D'Nyala and Shongoane sites. Some of the participants were employed at D'Nyala, with some being part of the management, and others residents from Shongoane. Out of these, a sample of eight workers involved in bush clearing at Shongoane and six involved in bush clearing and management in $\mathrm{D}^{\prime} \mathrm{Ny}$ ala were purposively selected to partake in the study.

Comprised of both males and females ranging between 22 and 55 years in age, most of the participants had at least six months' experience of bush clearing and restoration projects and were previously unemployed or recently retrenched. In sum, the group consisted of 6 general workers, 2 group supervisors, 2 nature conservationists, 3 tax and revenue collectors and 1 project coordinator, representing all the skillsets and functions within the project.

Purposive sampling was used because this study aimed to target those who were directly involved and could provide a first-hand/informed account of how they benefited from the bush clearing and/or restoration projects [43].

\subsection{Procedure and Ethical Considerations}

The North-West University's Research Ethics Regulatory Committee (NWU-00120-18-A1) granted permission for the study. The principles and the regulations issued by the university's registered ethics committee regarding research where human subjects are involved were taken into consideration during all of the phases in the study. Participation was voluntary and, having been assured that their identities would remain confidential, participants consented to partaking in the study individually. Interviews lasting approximately 20 to 35 min were conducted at participants' places of work, in the field at the village or at the offices of the nature reserve. In all instances, participants could choose a venue and time that suited them best.

\subsection{Data Gathering}

Data were gathered by means of semi-structured interviews after the bush clearing and restoration projects had been completed. The questions asked during the interviews focused on participants' first-hand experiences as direct beneficiaries of these projects from the time of the inception of the project right up until completion. The three questions asked were similar in nature, with the exception that question 3 was adopted for the sake of site relevance (see Table 1). Given that interviews were conducted face-to-face, a participant's response to question 3 led to follow-up questions being asked where necessary in an attempt to gain a better understanding.

At D'Nyala Nature Reserve, all participants were interviewed. However, at Shongoane only nine workers were interviewed because at that point, saturation had been reached. In other words, it was clear at this point that no new information would be discovered and that conducting further interviews would lead to redundancy in the data collected. In total, data were collected from 14 participants from the two sites. All interviews were recorded digitally. 
Table 1. Interview schedule for Shongoane village and D'Nyala Nature Reserve.

\begin{tabular}{|c|c|}
\hline Topics & Questions \\
\hline (1) Bush clearing programme's main benefit & $\begin{array}{l}\text { Can you please describe what the main benefit that } \\
\text { you received was and how you used the provision } \\
\text { from participating in the bush clearing project? } \\
\text { What was your involvement directly or indirectly in } \\
\text { the bush clearing and restoration project? }\end{array}$ \\
\hline (2) Programme influences and the outcome & $\begin{array}{l}\text { Can you describe how you experienced the } \\
\text { programme: did it help in any way, or not at all? }\end{array}$ \\
\hline $\begin{array}{l}\text { (3) Possible lasting/sustainable impact of the bush } \\
\text { clearing programme }\end{array}$ & $\begin{array}{l}\text { (a) Shongoane participants: What changes, if any, } \\
\text { have you seen in your well-being (included here are } \\
\text { money for school fees, food and basic needs, etc.) as a } \\
\text { result of participating in the bush clearing and } \\
\text { restoration project? Is there anything that you gained } \\
\text { from the project that will help you in future? Please } \\
\text { describe if there are any. } \\
\text { (b) D'Nyala participants: What changes, if any, } \\
\text { have you seen in the nature reserve (included here are } \\
\text { generating money, enhancing game/nature viewing, } \\
\text { etc.) as a result of participating in the bush clearing } \\
\text { and restoration project? }\end{array}$ \\
\hline
\end{tabular}

\subsection{Data Analysis}

Data were thematically analysed. Thematic analysis is a method commonly used in the analysis of qualitative data $[44,45]$. Audio recordings were transcribed and analysed by means of a thematic content analysis, a six-step procedure. The steps involve (1) data familiarising, (2) assigning preliminary codes to the data in order to describe the content, (3) theme coding across the interviews, (4) the reviewing of themes, (5) the defining and naming of themes and lastly (6) producing results from the thematically categorised data $[45,46]$. This method allows for the flexible identification of themes and sub-themes; moreover, because this was a deductive study, it was easier to select themes, as the exact interest was known.

After each interview, the researcher reflected on and explained the information provided by the participant in an attempt to ensure that the quality of the information was retained. As a further safeguard to ensure that the study's findings were not influenced by researcher bias, a gatekeeper with a deep understanding of the bush clearing and restoration projects in and around the nature reserve was employed to ensure the trustworthiness of the data within the context of the study.

\section{Results}

This study set out to investigate the socio-economic benefits addressed by means of bush clearing and restoration projects deployed in and around the Lephalale municipality in the Limpopo Province. The study was conducted at two sites, namely the D'Nyala Nature Reserve and Shongoane, a rural village in the north-eastern part of Lephalale.

As explained above, data collected by means of interviews conducted with purposively selected participants were thematically analysed. Based on the analysis and to illustrate the differences between the benefits derived by participants employed at the D'Nyala Nature Reserve versus participants who resided in Shongoane village, Figures 2 and 3 below highlight the three most important themes emerging from the nature reserve's data and the data derived from participants who resided in the village. 


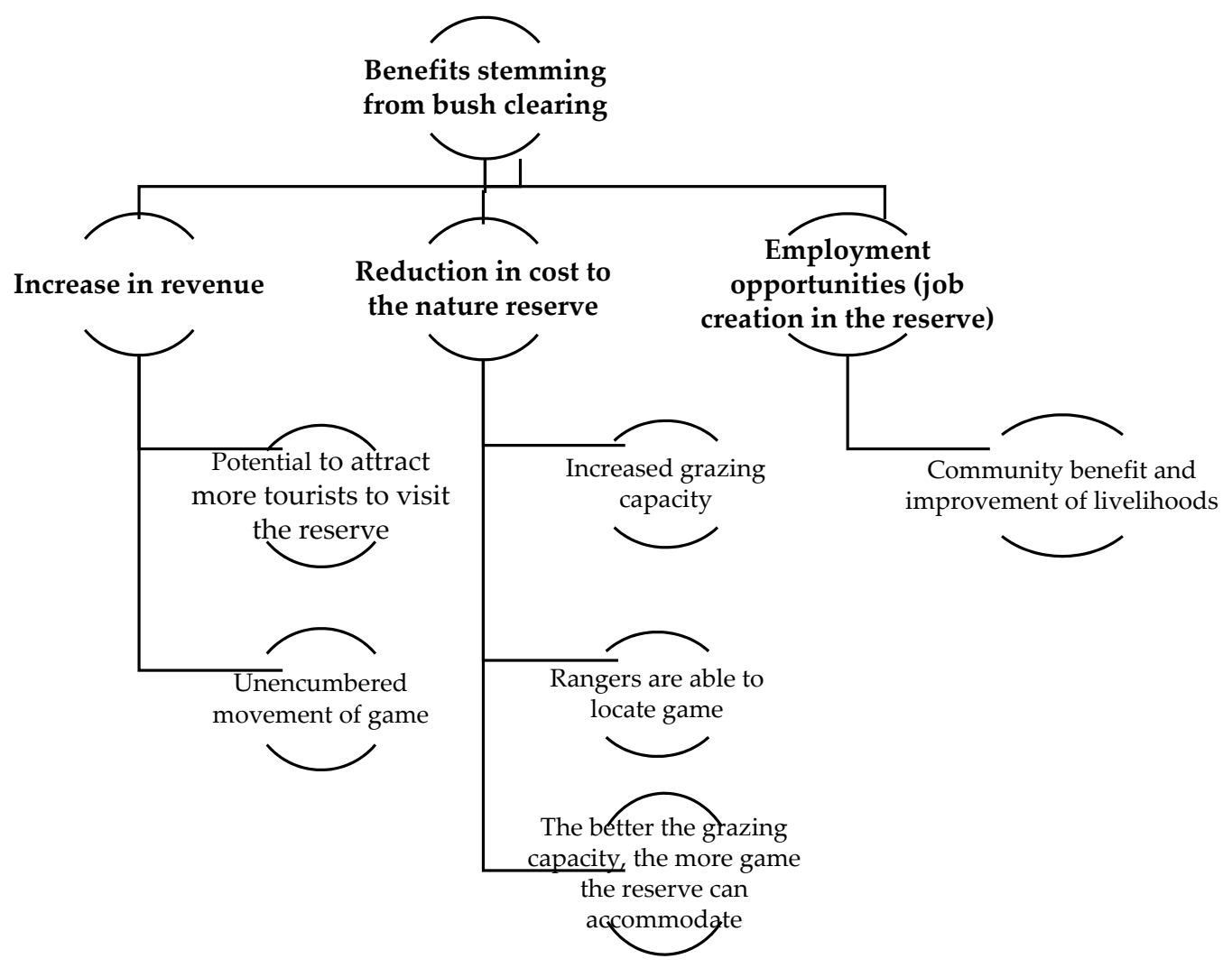

Figure 2. Thematically analysed benefits for D'Nyala Nature Reserve.

\subsection{Emerging Themes: D'Nyala Nature Reserve}

Bush clearing in the reserve commenced in 2016. Up until that point, the reserve was so heavily encroached upon that even the entrance area was not quite accessible. As illustrated in Figure 2 below, the following themes emerged as direct benefits resulting from bush clearing and restoration work in the reserve.

\subsubsection{Increase in Revenue}

Participants were in agreement that bush clearing definitely improved visibility within the reserve. Where overgrown patches made it difficult for tourists to spot game before, they could now observe wildlife unhindered from afar. If tourists were assured that they were likely to spot game unhindered, they were more likely to be attracted to the nature reserve and if tourists were attracted, the nature reserve's revenue was bound to increase.

Since the nature reserve also offers opportunities for recreational hunting, participants observed that as a result of bush clearing, game was less encumbered and free to roam more widely. Before, there were areas that even rangers found difficult to navigate.

"There used to be a lot of bush even closer to the tar road, sometimes you could see the animal but when you try to get closer it would run and hide into the bush and it would be difficult to locate it."

Participant \#1, 42

\subsubsection{Reduction in Costs}

The reserve is host to a whole array of animals, including several species of antelope. Bush clearing resulted in increased grazing capacity and a reduction in the need to supply supplementary feed. 
In addition, participants working for the reserve remarked that they now had to spend fewer man-hours on tracking and monitoring game because, with less camouflage, the animals were easier to spot.

"So far where it is cleared especially sickle bush, there is a visible change of vegetation of which is beneficial for the animals because there is more grass to graze." Participant \#3, 33

\subsubsection{Employment Opportunities}

In addition to the biophysical and financial benefits highlighted above, all participants who worked for the nature reserve highlighted the prospect of employment as an added socio-economic benefit. According to them, hundreds of job opportunities could be offered to local disadvantaged "bush clearers" who, by participating in these projects, could lessen the financial burden on their families and improve their livelihoods.

"I am very happy because the project has employed many people from outside the nature reserve especially from the villages. At least month end the people can get something to buy food, half a loaf is better than nothing." Participant \#2, 56

\subsection{Emerging Themes: Shongoane Village}

As can be observed from Figure 3 below, community participants residing in Shongoane derived several direct and indirect socio-economic benefits from their participation in bush clearing and restoration projects.

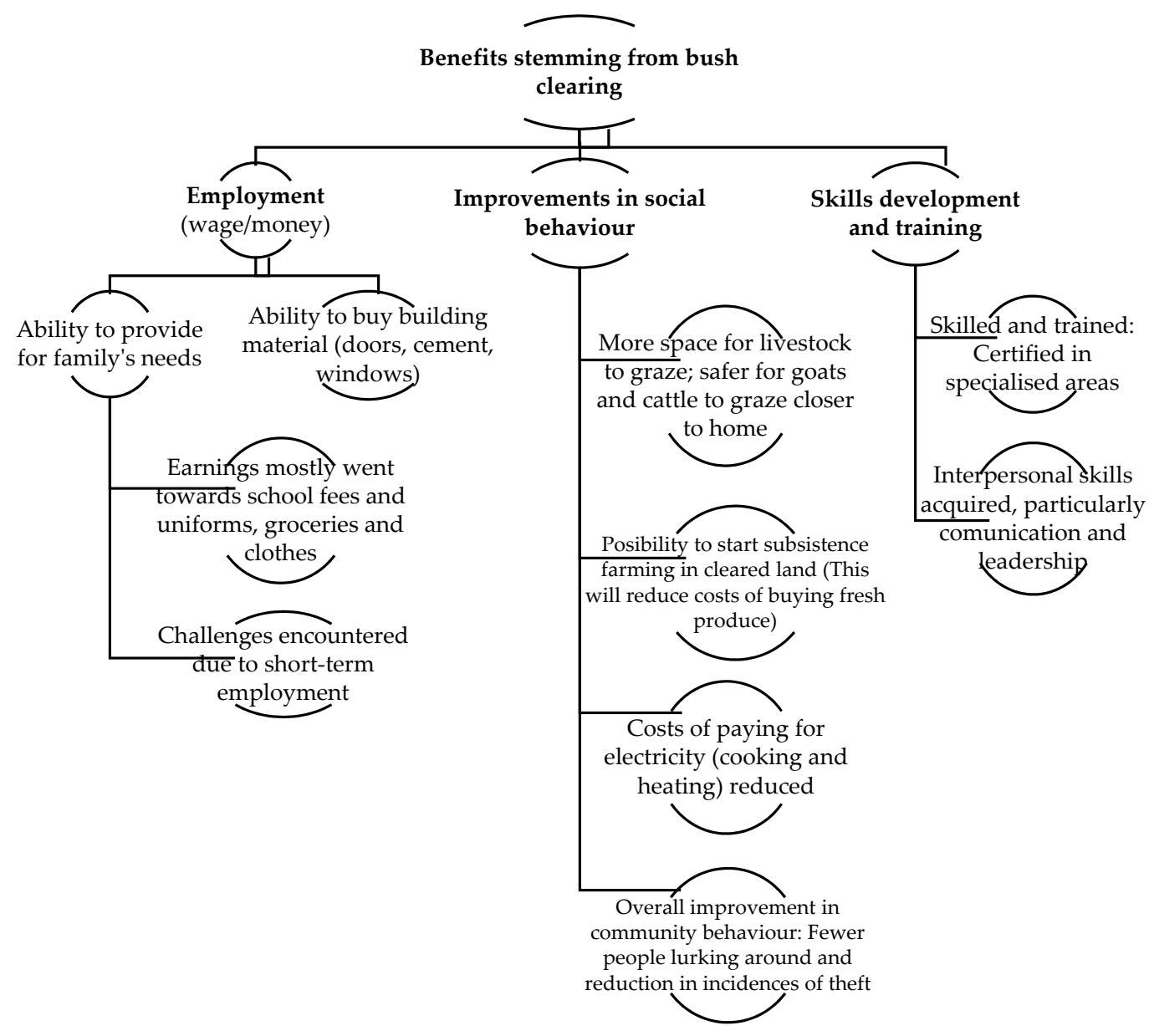

Figure 3. Thematically analysed benefits for Shongoane village. 


\subsubsection{Employment}

The first benefit participants residing in Shongoane alluded to was the wage (money) they earned. With this money, they could take care of their family's basic needs by buying food and clothes and paying for school fees and uniforms. Secondly, the wage enabled them to buy building materials such as doors, windows and cement:

"This money has helped me because my husband is unemployed. We have a building project and the money has helped to buy doors and windows so that we can finish building the room." Participant \#8, 37

On the downside, the wage participants earned did not provide for much more than basic needs and perhaps a few extras. For example, it did not extend to covering the actual costs of adding another room to a home or to undertaking any other long-term project that would improve participants' well-being:

"Not much of my well-being has changed because the money is too little, I can only buy small things like groceries." Participant \#7, 31

Furthermore, participants found that the term of their contracts was too short. As a rule, contracts were renewed on a three-month basis. Nevertheless, most participants said that working on a short-term basis was better than not working at all.

\subsubsection{Improvements in Social Behaviour}

Given that participants resided in or near the sites where bush clearing and restoration work took place, they were in a position to observe a marked change in the behaviour of fellow community members. The community acknowledged the productiveness of the environment and how it could eventually be a cost-effective resource in their lives. What they observed was that people living in and around the sites where bush clearing took place came to collect cut branches to use as firewood for cooking and heating. In one instance, a female participant who came to collect firewood with her children said that since it was expensive to operate an electrical stove, the wood they collected helped them to save on electricity. Furthermore, cleared land space resulted in more space where community members' livestock could graze nearby in areas where their owners could keep an eye on their goats and cattle to ensure that they remained safe. This gave them some sense of security knowing that they were able to check on their livestock close by. Although the community had not yet embarked on small-scale crop farming, many alluded to the possibility of being able to start subsistence farming on the cleared land in future, as this would help in reducing the expenses of having to buy fresh produce from shops or markets. Regarding the general social environment and the behaviour of the community, participants also remarked that since people were gainfully occupied, fewer were lurking around, which, according to them, resulted in a reduction in incidences of theft.

\subsubsection{Skills Development and Training}

Many young people from the village are unemployed and have never had the opportunity to gain work experience and/or to improve their skills through training. Given that those who participated in the bush clearing and restoration projects were afforded the opportunity to be formally certified in, amongst others, snake control and herbicide application, the knowledge and skills they acquired in the course of their participation would undoubtedly improve their prospects of finding gainful employment in future.

"This project has not only benefited me, but others too because most people were unemployed in our village and now we are gaining experience." Participant \#5, 29

Besides the practical knowledge and skills participants obtained, many also remarked that their interpersonal skills and ability to communicate with and lead people had improved in the course of their participation: 
"We work well together and we listen to each other. If there is a problem, we solve it well without a fight." Participant \#5, 29

\section{Discussion}

Ecosystems provide a range of services, many of which are important to local communities and human well-being [27]. In South Africa, an important driver of ecosystem decline is bush encroachment and the spread of invasive alien plant species [26,27].

Given that the D'Nyala Nature Reserve is considered a protected area in South Africa that is earmarked by the Department of Environmental Affairs as an area where biodiversity should be preserved, several projects involving members of the surrounding communities were launched in 2016 under the auspices of the department's Natural Recourse Management (NRM) and Expanded Public Works (EPWP) programmes. These projects mostly entailed the removal of invasive alien plants, the restoration of rangeland and land management.

As pointed out by De Klerk [47] and Arbieu et al. [48], reduced visibility caused by bush encroachment decreases the tourism potential of lands since this phenomenon has an impact on tourists' ability to view game in their natural habitat. Furthermore, Ward [26] found that since bush encroachment has a negative impact on game's ability to graze freely, the carrying capacity of land is reduced considerably.

From a biophysical perspective, the manager of the D'Nyala Nature Reserve reported that the bush clearing and restoration projects conducted under the auspices of the NRM programme succeeded in improving the environmental state of the reserve considerably. This not only led to a perceived increase in revenue because tourists would find the reserve more attractive but also resulted in cost savings since emerging grass species lessened the need to provide game with supplemental feed. In addition, keepers of livestock in Shongoane village found that the bush clearing and restoration projects enabled them to keep their communal goats and cattle safely closer to their homes, and conceded that the improvement in grazing would, in the long run, result in livestock fetching higher prices at market.

The study sought to understand the link between restoration (biodiversity) and ecosystem services (social benefits). The results indicate that bush clearing and restoration projects had a significant impact both on the local community and on the nearby nature reserve in the provision of employment opportunities for community members and increased the nature reserve's prospects of generating a higher income. These findings regarding socio-economic impacts largely correlate with those reported by Saayman et al. [7] and Stafford et al. in earlier studies.

From the thematic analysis, it is clear that those participants who were directly associated with the nature reserve (i.e., $\mathrm{D}^{\prime} \mathrm{Ny}$ ala) as well as those who resided in the nearby village (i.e., Shongoane) viewed employment, albeit temporarily, as a major benefit derived from bush clearing and restoration projects.

In essence, the value of benefits for community members has two components: firstly, it has a monetary value (i.e., wages earned) and, secondly, it has an empowerment value in as far as participants could improve their employability by being afforded the opportunity to acquire skills and to be trained in specialist areas such as snake control and herbicide application, mastery of which was awarded a formal certificate. The notion that participants can improve their levels of education in the course of working on bush clearing and restoration projects is supported by Lal [25], who found education to be an important indirect socio-economic benefit associated with the prospect of finding employment in future.

Nevertheless, this study found that there was a marked difference between female and male participants' satisfaction with the monetary benefits derived as a result of being employed to execute bush clearing and restoration projects. Most female participants had families with at least two children in the household and were of the opinion that their participation greatly helped to take care of basic needs (i.e., buying groceries and clothes and paying for school fees and school uniforms). Most male participants, on the other hand, were of the opinion that the wages were too low and could barely cover basic their necessities, let alone provide for major projects such as renovations and additions 
to their homes. Gcabo [49] also confirmed that money has different meanings to different genders, and therefore influences the different needs for which it is used. Furthermore, the results in [49] indicated that for women, money is the basis for survival at home as it is used to serve basic needs, and to take care of the family, while for men, money means economic and social status and pride: the less you have, the less important you are considered in the community [50].

Despite this contradiction, it can be concluded that the bush clearing and restoration activities undertaken in Lephalale did indeed help to create temporary employment opportunities for members of the community and resulted in socio-economic benefits being created, a view that is supported by Francis et al. [10] and Stafford et al. [27].

Of concern here is that even though most community participants were appreciative of the financial relief and the incumbent benefits temporary employment offered [25], they failed to understand why their employment would only be of a temporary nature. This concern regarding the sustainability of projects and the ability to keep supporting participants' livelihoods once employment contracts have expired was also raised in a study conducted by Akama and Kieti [51]. Of interest here is that the participants employed at the nature reserve remarked that even though the community members were dissatisfied about their income and short-term contracts, "half a loaf is better than nothing". In the integrated development plan of Lephalale [38], the importance of the tourism industry to the economy was realised. Even though the expansion of the tourism industry is highly dependent on its strong links to industrial operations, it will give an opportunity for future income generation for unemployed rural community members.

As found by Arnold et al. [10] and DeCaro and Stokes [12], positive outcomes are not always guaranteed in community-based projects. In this instance, too, both the nature reserve and the community had to deal with one common challenge, namely the low compensation offered to workers involved in the bush clearing and restoration projects. As a result, the nature reserve especially had to deal with unhappy and discouraged workers.

Furthermore, since the introduction of the projects first had to be vetted by the village chief, politically motivated and/or personal interests might have resulted in community members not deriving the full benefit of the projects. In this regard, Druschke and Hychka [14] pointed out that communication and mutual cooperation are key to the process of community-based projects since they shape the quality of community engagement which, in turn, can translate to all parties benefiting.

Nevertheless, as discussed above, the overall benefits derived from the bush clearing and restoration projects deployed in $\mathrm{D}^{\prime} \mathrm{Ny}$ ala and Shongoane far outweigh the challenges.

\section{Conclusions}

Bush encroachment and the invasion of alien plant species alter the balance of natural ecosystems. As illustrated by the bush clearing and restoration projects undertaken in the D'Nyala Nature Reserve and Shongoane village, it is possible for both nature reserves and communities to derive some socio-economic benefits from communal attempts to address this issue. As is evident from the findings of this study, community members benefited directly and indirectly because the bush clearing and restoration projects created employment opportunities and afforded members of the community opportunities to undergo training and, in the process, to acquire marketable skills and knowledge. Likewise, the nature reserve benefited from the bush clearing and restoration projects because more tourists would potentially now find the reserve more attractive. The increased grazing capacity meant that the reserve could cut on supplementary feeds for game.

Despite the challenges encountered in implementing land restoration projects in and around Lephalale, it is obvious that the socio-economic benefits derived far outweigh the negatives and that there is every reason to institute projects of a similar nature elsewhere in future.

Author Contributions: Conceptualisation, T.M., H.C. and K.K.; Formal analysis, T.M.; Investigation, T.M., H.C. and K.K.; Methodology, T.M. and H.C.; Supervision, H.C., K.K. and G.C.; Writing-original draft, T.M.; 
Writing-review and editing, H.C., K.K. and G.C. All authors have read and agreed to the published version of the manuscript.

Funding: This project was funded by the Department of Environment, Forestry and Fisheries (DEFF), formerly known as the Department of Environmental Affairs (DEA). Funding comes under the department's Natural Resource Management (NRM), Expanded Public Works (EPWP) and Female Empowerment (FEM Power) programmes. Additional funding was made available from the Agricultural Research Council, Pretoria, South Africa and North-West University, Potchefstroom, South Africa. The first author is very grateful for all funding provided towards her PhD studies.

Acknowledgments: The authors kindly thank the Shongoane community and the D'Nyala Nature Reserve for their technical support and for allowing research to be conducted on their land.

Conflicts of Interest: The authors declare no conflicts of interest.

\section{References}

1. Cooper, C.B.; Dickinson, J.; Phillips, T.; Bonney, R. Citizen Science as a tool for conservation in residential ecosystems. Ecol. Soc. 2007, 12, 2. [CrossRef]

2. Mace, G.M.; Norris, K.; Fitter, A.H. Biodiversity and ecosystem services: A multilayered relationship. Trends Ecol. Evol. 2012, 27, 19-26. [CrossRef] [PubMed]

3. Dorondel, T.; Arma, I.; Florian, V.; Rusu, M.; Posner, C.; Erban, S. Policy Report Concerning the Socio-Economic and Environmental Transformations in the Lower Danube Floodplain. Available online: https://www.researchgate.net/profile/Stefan_Dorondel/publication/308886022_POLICY_REPORT_ CONCERNING_THE_SOCIOECONOMIC_AND_ENVIRONMENTAL_TRANSFORMATIONS_IN_THE_ LOWER_DANUBE_FLOODPLAIN/links/57f4827c08ae280dd0b74940/POLICY-REPORT-CONCERNINGTHE-SOCIO-ECONOMIC-AND-ENVIRONMENTAL-TRANSFORMATIONS-IN-THE-LOWER-

DANUBE-FLOODPLAIN.pdf (accessed on 8 June 2020).

4. Berkes, F.; Folke, C. Linking social and ecological systems for resilience and sustainability. Link Soc. Ecol. Syst. Manag. Pract. Soc. Mech. Build. Resil. 1998, 1, 4.

5. Meek, M.H.; Wells, C.; Tomalty, K.M.; Ashander, J.; Cole, E.M.; Gille, D.A.; Putman, B.J.; Rose, J.P.; Savoca, M.S.; Yamane, L.; et al. Fear of failure in conservation: The problem and potential solutions to aid conservation of extremely small populations. Biol. Conserv. 2015, 184, 209-217. [CrossRef]

6. Simelane, T.S.; Kerley, G.I.H.; Knight, M.H. Reflections on the relationships between communities and conservation areas of South Africa: The case of five South African national parks. Koedoe 2006, 49, 85-102. [CrossRef]

7. Saayman, M.; Van der Merwe, P.; Saayman, A.; Mouton, M.E. The socio-economic impact of an urban park: The case of Wilderness National Park. J. Policy Res. Tour. Leis. Events 2009, 1, 247-264. [CrossRef]

8. Alcamo, J. Ecosystems and Human Well-Being: A Framework for Assessment; Island Press: Washington, DC, USA, 2003; p. 245.

9. Brooks, T.M.; Mittermeier, R.A.; da Fonseca, G.A.; Gerlach, J.; Hoffmann, M.; Lamoreux, J.F.; Mittermeier, C.G.; Pilgrim, J.D.; Rodrigues, A.S. Global biodiversity conservation priorities. Science 2006, 313, 58-61. [CrossRef]

10. Francis, G.; Edinger, R.; Becker, K. A Concept for Simultaneous Wasteland Reclamation, Fuel Production, and Socio-economic Development in Degraded Areas in India: Need, Potential and Perspectives of Jatropha Plantations. In Natural Resources Forum; Blackwell Publishing Ltd.: Oxford, UK, 2005; Volume 29, pp. 12-24.

11. Arnold, J.S.; Koro-Ljungberg, M.; Bartels, W.L. Power and conflict in adaptive management: Analysing the discourse of riparian management on public lands. Ecol. Soc. 2012, 17, 19. [CrossRef]

12. DeCaro, D.A.; Stokes, M.K. Public participation and institutional fit: A social-psychological perspective. Ecol. Soc. 2013, 18, 4. [CrossRef]

13. Bernhardt, E.S.; Sudduth, E.B.; Palmer, M.A.; Allan, J.D.; Meyer, J.L.; Alexander, G.; Follastad-Shah, J.; Hassett, B.; Jenkinson, R.; Lave, R.; et al. Restoring rivers one reach at a time: Results from a survey of US river restoration practitioners. Restor. Ecol. 2007, 15, 482-493. [CrossRef]

14. Druschke, C.G.; Hychka, K.C. Manager perspectives on communication and public engagement in ecological restoration project success. Ecol. Soc. 2015, 20, 1. [CrossRef]

15. Reid, H. Ecosystem-and community-based adaptation: Learning from community-based natural resource management. Clim. Dev. 2016, 8, 4-9. [CrossRef] 
16. Fox, C.A.; Reo, N.J.; Turner, D.A.; Cook, J.; Dituri, F.; Fessell, B.; Jenkins, J.; Johnson, A.; Rakena, T.M.; Riley, C.; et al. "The river is us; the river is in our veins": Re-defining river restoration in three Indigenous communities. Sustain. Sci. 2017, 12, 521-533. [CrossRef]

17. Browder, J.O. Conservation and development projects in the Brazilian Amazon: Lessons from the Community Initiative Program in Rondônia. Environ. Manag. 2002, 29, 750-762. [CrossRef] [PubMed]

18. Muhar, S.; Januschke, K.; Kail, J.; Poppe, M.; Schmutz, S.; Hering, D.; Buijse, A.D. Evaluating good-practice cases for river restoration across Europe: Context, methodological framework, selected results and recommendations. Hydrobiologia 2016, 769, 3-19. [CrossRef]

19. Vermaat, J.E.; Wagtendonk, A.J.; Brouwer, R.; Sheremet, O.; Ansink, E.; Brockhoff, T.; Plug, M.; Hellsten, S.; Aroviita, J.; Tylec, L.; et al. Assessing the societal benefits of river restoration using the ecosystem services approach. Hydrobiologia 2016, 769, 121-135. [CrossRef]

20. Roy, M.B.; Roy, P.K.; Samal, N.R.; Mazumdar, A. Socio-economic valuations of wetland based occupations of lower gangetic basin through participatory approach. Environ. Nat. Resour. Res. 2012, 2, 30.

21. Patel, M.; Kok, K.; Rothman, D.S. Participatory scenario construction in land use analysis: An insight into the experiences created by stakeholder involvement in the Northern Mediterranean. Land Use Policy 2007, 24 , 546-561. [CrossRef]

22. Dougill, A.J.; Akanyang, L.; Perkins, J.; Eckardt, F.D.; Stringer, L.C.; Favretto, N.; Atlhopheng, J.; Mulale, K. Land use, rangeland degradation and ecological changes in the southern Kalahari, Botswana. Afr. J. Ecol. 2016, 54, 59-67. [CrossRef]

23. Mokgotsi, R.O. Effects of Bush Encroachment Control in a Communal Managed Area in the Taung Region. Ph.D. Thesis, North-West University, North West Province, South Africa, 2018.

24. Thornton, P.K.; Gerber, P.J. Climate change and the growth of the livestock sector in developing countries. Mitig. Adapt. Strateg. Glob. Chang. 2010, 15, 169-184. [CrossRef]

25. Lal, R. Enhancing crop yields in the developing countries through restoration of the soil organic carbon pool in agricultural lands. Land Degrad. Dev. 2006, 17, 197-209. [CrossRef]

26. Ward, D. Do we understand the causes of bush encroachment in African savannas? Afr. J. Range Forage Sci. 2005, 22, 101-105. [CrossRef]

27. Stafford, W.; Birch, C.; Etter, H.; Blanchard, R.; Mudavanhu, S.; Angelstam, P.; Blignaut, J.; Ferreira, L.; Marais, $\mathrm{C}$. The economics of landscape restoration: Benefits of controlling bush encroachment and invasive plant species in South Africa and Namibia. Ecosyst. Serv. 2017, 27, 193-202. [CrossRef]

28. Adams, W.M.; Hutton, J. People, parks and poverty: Political ecology and biodiversity conservation. Conserv. Soc. 2007, 5, 147-183.

29. Mukheibir, P.; Sparks, D. Water Resource Management and Climate Change in South Africa: Visions, Driving Factors and Sustainable Development Indicators. In Report for Phase I of the Sustainable Development and Climate Change Project; Energy and Development Research Centre (EDRC): Univesity of Cape Town, South Africa, 2003. Available online: http://www.erc.uct.ac.za/sites/default/files/image_tool/images/119/Paperspre2004/03Mukheibir-Sparks_Water_resource_management.pdf (accessed on 23 January 2020).

30. Donnenfeld, Z.; Crookes, C.; Hedden, S. A delicate balance: Water scarcity in South Africa. ISS S. Afr. Rep. 2018, 13, 1-24.

31. Hoffman, T.; Ashwell, A. Nature Divided: Land Degradation in South Africa; University of Cape Town Press: Cape Town, South Africa, 2001; Volume 43.

32. Alexander, M.; The Nine Provinces of South Africa. South Africa Gateway 2019. Available online: https: //www.southafrica-info.com/land/nine-provinces-south-africa/text=Limpopo (accessed on 8 June 2020).

33. Gibson, D.J. Land Degradation in the Limpopo Province, South Africa. Ph.D. Thesis, University of the Witwatersrand, Gauteng Province, South Africa, 2006.

34. Lukomska, N.; Quaas, M.F.; Baumgärtner, S. Bush encroachment control and risk management in semi-arid rangelands. J. Environ. Manag. 2014, 145, 24-34. [CrossRef]

35. Hoffman, M.T.; Todd, S. A national review of land degradation in South Africa: The influence of biophysical and socio-economic factors. J. S. Afr. Stud. 2000, 26, 743-758. [CrossRef]

36. Grossman, D.; Holden, P. Case Studies on Successful Southern African NRM Initiatives and Their Impacts on Poverty and Governance; Report for IUCN/USAID Frame: Pretoria, South Africa, 2007.

37. Aronson, J.; Clewell, A.F.; Blignaut, J.N.; Milton, S.J. Ecological restoration: A new frontier for nature conservation and economics. J. Nat. Conserv. 2006, 14, 135-139. [CrossRef] 
38. Integrated Development Plan (IDP). Available online: http://www.lephalale.gov.za/docs/SDBIP/Final\% 20IDP\%202018-19.pdf (accessed on 13 March 2019).

39. Moon, K.; Brewer, T.D.; Januchowski-Hartley, S.R.; Adams, V.M.; Blackman, D.A. A guideline to improve qualitative social science publishing in ecology and conservation journals. Ecol. Soc. 2016, 21, 3. [CrossRef]

40. Petty, N.J.; Thomson, O.P.; Stew, G. Ready for a paradigm shift? Part 1: Introducing the philosophy of qualitative research. Man. Ther. 2012, 17, 267-274. [CrossRef]

41. Khagram, S.; Nicholas, K.A.; Bever, D.M.; Warren, J.; Richards, E.H.; Oleson, K.; Kitzes, J.; Katz, R.; Hwang, R.; Goldman, R.; et al. Thinking about knowing: Conceptual foundations for interdisciplinary environmental research. Environ. Conserv. 2010, 37, 388-397. [CrossRef]

42. Hammersley, M. The issue of quality in qualitative research. Int. J. Res. Method Educ. 2007, 30, $287-305$. [CrossRef]

43. Johnson, R.; Waterfield, J. Making words count: The value of qualitative research. Physiother. Res. Int. 2004, 9, 121-131. [CrossRef] [PubMed]

44. Vaismoradi, M.; Turunen, H.; Bondas, T. Content analysis and thematic analysis: Implications for conducting a qualitative descriptive study. Nurs. Health Sci. 2013, 15, 398-405. [CrossRef] [PubMed]

45. Gibbs, G.R. Thematic coding and categorizing. Anal. Qual. Data Lond. Sage 2007, 38-56. [CrossRef]

46. Braun, V.; Clarke, V. Using thematic analysis in psychology. Qual. Res. Psychol. 2006, 3, 77-101. [CrossRef]

47. De Klerk, J.N. Bush Encroachment in Namibia. In Rep Phase 1 of the Bush Encroachment Research, Monitoring and Management Project; Ministry of Environment and Tourism: Windhoek, Namibia, 2004; p. 253. Available online: http://dasnamibia.org/wp-content/uploads/2016/07/De-Klerk-Bush-Encoachment-in-Namibia-2004. pdf (accessed on 16 September 2019).

48. Arbieu, U.; Grünewald, C.; Schleuning, M.; Böhning-Gaese, K. The importance of vegetation density for tourists' wildlife viewing experience and satisfaction in African savannah ecosystems. PLOS ONE 2017, $12,9$. [CrossRef]

49. Gcabo, R.P.E. Money and Power in Household Management: Experiences of Black South African Women. Ph.D. Thesis, University of Pretoria, Gauteng Province, South Africa, 2005.

50. Posel, D.R. Who are the heads of household, what do they do, and is the concept of headship useful? An analysis of headship in South Africa. Dev. South Afr. 2001, 18, 651-670. [CrossRef]

51. Akama, J.S.; Kieti, D. Tourism and socio-economic development in developing countries: A case study of Mombasa Resort in Kenya. J. Sustain. Tour. 2007, 15, 735-748. [CrossRef] 